\title{
Contra los gravísimos males que combaten la Religión y el Estado: Inquisición e Iglesia en Cuba a inicios del siglo XIX
}

\section{Against the Most Grievous Evils Combated by Religion and the State: Inquisition and Church in Cuba at the beginning of the $19^{\text {th }}$ century}

CONSOLACIÓN FERNÁNDEZ MELLÉN

Centro de Estudos de História Religiosa

Universidade Católica Portuguesa

cfernandezmellen@gmail.com

\section{RESUMEN}

Entre 1810 y 1824, las Antillas españolas fueron testigos de cómo el territorio de la América continental iniciaba, maduraba y culminaba su proceso de independencia y de una España que, a partir de la invasión francesa de la peninsula Ibérica en 1808, vivió sus dos primeras experiencias liberales. Ambos desarrollos históricos supusieron la subversión del orden que representaba la monarquia absoluta, al momento en la persona de Fernando VII, y sus consecuencias se dejaron sentir en las islas. Tras el restablecimiento del absolutismo, en Cuba surgieron voces que buscaron adaptar la actividad inquisitorial a una nueva realidad que, impuesta por acontecimientos externos, condicionó el desarrollo y la efectividad de la actuación de los ministros de la Inquisición en la isla. El presente artículo se propone rescatar un proyecto de establecer un nuevo tribunal de Inquisición

* El título de este artículo se inspira y reproduce en buena medida las palabras escritas por el comisario de la Inquisición de La Habana, Esteban Manuel de Elosua (Representación de Esteban Manuel de Elosua, La Habana, 29 de abril de 1816, Archivo General de Indias [en adelante AGI], Indiferente General, 3014B).

HISTORICA XLIII.2 (2019): 113-146 / ISSN 0252-8894

https://doi.org/10.18800/historica.201902.004 
en La Habana, que fue presentado como un instrumento para el control de las ideas, la defensa de la religión y contra la herejía.

Palabras clave: Inquisición, Cuba, Puerto Rico, Ilustración, Liberalismo.

\section{ABSTRACT}

Between 1810 and 1824 the Spanish Antilles witnessed the beginning, maturation and culmination of Independence in the continental American territories, while Spain-beginning with the French invasion of the Iberian Peninsula in 1808-lived through its first two experiences with Liberalism. Neither of these historical developments would have been possible without the subversion of the absolute monarchy - at that time in the person of Fernando VII-, the consequences of which were perceived in the islands. After the restoration of absolutism, emerging voices in Cuba tried to adapt inquisitorial structures to the new reality that, imposed by external events, conditioned the development and effective action of the Inquisition on the islands. This article aims to reconstruct a project to establish a new Inquisition tribunal in Havana, which was presented as an appropriate instrument for the control of ideas, the defense of religion and against heresy.

Keywords: Inquisition, Cuba, Puerto Rico, Enlightenment, Liberalism.

$\mathrm{D}$ urante la independencia americana, los tres tribunales de la Inquisición en América vieron amenazada, por primera vez en su historia, su propia supervivencia, en un proceso que concluiría con su supresión. Como no podía ser de otra forma, las consecuencias de la situación bélica se dejaron sentir a todos los niveles de la estructura organizativa inquisitorial. En Cuba, sus comisarios sufrieron la incertidumbre de saber a los miembros del tribunal de Cartagena de Indias en el exilio y de ver cuestionada por algunas autoridades la validez de los decretos que emanaban de una autoridad que se hallaba en un territorio bajo el control de las autoridades revolucionarias.

Encrucijada de caminos, la isla y particularmente su capital, La Habana, fue un hervidero de ideas y foco de atracción de comerciantes y tran- 
seúntes, nacionales y extranjeros, muchos de los cuales llegaron atraídos de una potente actividad económica generada a la sombra del cultivo del azúcar, del comercio de esclavos y de la libertad del tráfico comercial. En este contexto, las autoridades eclesiásticas e inquisitoriales se izaron en guardianes de la religión, de la fe y de la conservación del orden político y social. En su defensa desplegaron una intensa actividad, la cual fue fuente de conflictos entre ambas jurisdicciones. El decreto de las Cortes de Cádiz que suprimió la Inquisición devolvió a los obispos cubanos el ejercicio de unas prerrogativas inquisitoriales que habían defendido como inherentes a su dignidad episcopal. Así se explica que el obispo de La Habana saludase con alegría el decreto de abolición. Sin embargo, la última batalla se daría durante la Restauración. La abolición de todo lo obrado durante las cortes gaditanas abrió las puertas a aquellos que seguían creyendo en la necesidad y utilidad del Tribunal y, por ello, no dudaron en presentar su proyecto para la creación de uno en La Habana.

INQUISICIÓN Y POLÍTICA EN CUBA A COMIENZOS DEL XIX

En 1816 el comisario de la Inquisición de Cartagena de Indias en La Habana, Esteban Manuel de Elosua, pedía a Fernando VII el establecimiento de un tribunal de la Inquisición en esta ciudad, que fuera independiente del Santo Oficio de Cartagena de Indias, del cual había dependido el territorio insultar desde $1610 .{ }^{1}$ Durante el siglo XVI, los obispos en Cuba ejercieron las facultades inquisitoriales, tal y como las habían detentado los diocesanos europeos — previamente a que el método inquisitorial se institucionalizase entre los siglos XII y XIII- y sus homólogos americanos previamente al establecimiento de los tribunales del Santo Oficio en México y Lima entre 1570 y $1571 .{ }^{2}$ Estas facultades les fueron disputadas a partir de 1607.

En dicho año, el Tribunal del Santo Oficio de México, con la clara intención de extender su jurisdicción sobre la conocida como Perla de

${ }^{1}$ AGI, Indiferente General, 3014B. Sobre el tribunal de Cartagena de Indias, véase Álvarez Alonso 1999; Splendiani 1997; Medina 1899.

${ }^{2}$ Brambilla 2006: 51-59; Hampe Martínez 1998; Greenleaf 1981 y 1988. 
las Antillas, nombró como comisario al guardián del convento de San Francisco, fray Francisco Carrasco, despojando al obispo fray Juan de las Cabezas Altamirano del título de «inquisidor ordinario». El diocesano apeló de la nómina al rey en un proceso que provocó un conflicto de competencias entre ambas jurisdicciones que, sin embargo, no impidió que el territorio insular quedase bajo la órbita del tribunal mexicano hasta 1610. A partir de entonces comenzaría a articularse en la isla una estructura inquisitorial propiamente dicha.

Hasta el momento, no existe ningún trabajo que aborde sistemáticamente el estudio de la presencia del tribunal en Cuba; sin embargo, los pocos datos publicados hablan de la existencia de un único comisario con sede en La Habana y de una red de familiares que se extendería por toda la isla, quienes a menudo entraron en conflicto con las autoridades civiles y religiosas. ${ }^{3}$ Estos trabajos explican que el hecho de que el comisario fijase su oficina en La Habana —cuando la sede del obispado se hallaba en la capital oriental de Santiago de Cuba- se debió al trasiego comercial y de personas de la ciudad habanera como puerto de una isla que fue descrita como «Llave del Nuevo Mundo y antemural de las Indias Occidentales». ${ }^{4}$ De hecho, entre las principales funciones del comisario, se encontró la facultad de visitar los barcos que atracaban en el puerto en búsqueda de libros prohibidos y la de controlar el contrabando. ${ }^{5}$ Esta vigilancia se hizo más necesaria a partir

3 Todos los datos sobre la Inquisición en Cuba en Marrero 1976: 79-85. Además de este trabajo, se ha publicado una monografía que aborda la actuación de este tribunal en los casos de brujería y hechicería en los años inmediatamente posteriores al establecimiento del tribunal de Cartagena de Indias, del que, como se verá, dependió la isla a partir de 1610 (Crespo 2018). La conflictividad entre las autoridades civiles, eclesiásticas e inquisitoriales ha sido particularmente estudiada para el caso de la Nueva España en el siglo XVII por Maqueda (2000: 93-186).

4 Este es el título de la obra que en 1761 publicó el regidor habanero José Martín Félix de Arrate y que no sería publicada hasta 1830, tras su muerte. La obra constituye una de las primeras historias conocidas de Cuba, si bien se limita fundamentalmente a recopilar noticias que ensalzan la posición y el papel de la ciudad y que justificaron el ilustrativo título. Al respecto, véase Le Riverend 2005: v-xiv.

5 Marrero 1976: 79, 82-85. Sobre el comercio de libros en Cuba en estos siglos, véase Sánchez 2008: 340-362. En contraposición a lo escrito por Marrero, Sánchez señala 


\section{de las últimas décadas del siglo XVIII. Refiriéndose a La Habana, el comisario de la Inquisición alertaba:}

por las preciosas producciones de la isla de Cuba, el comercio se ha hecho extensísimo y su puerto es frecuentado no sólo de buques de la nación española, más también de las extranjeras, de manera que es indispensable al exponente dedicar toda su vigilancia para impedir la introducción de lo que pueda perjudicar a nuestra sagrada religión, al estado y a las buenas costumbres y estar muy atento a que las perniciosas opiniones que abrazan y siguen los extranjeros enemigos de la santa fe, no inficionen a los católicos vasallos de V.M. ${ }^{6}$

Además de la comisaría de La Habana, existió otra comisaría principal en Santiago de Cuba, ${ }^{7}$ una ciudad que hasta 1789 — cuando se creó la diócesis de La Habana - fue la sede del único obispado de la isla y que en 1803 fue erigida en arzobispado. ${ }^{8}$ Nuestras investigaciones apuntan

que fue en 1634 cuando el Tribunal de Cartagena de Indias nombró un comisario en La Habana (Sánchez 2008: 353).

${ }^{6}$ Representación de Esteban Manuel Elosua al rey, La Habana, 18 de noviembre de 1815, AGI, Indiferente General, 3014B. A partir de 1790 se produjo el conocido como boom azucarero, cuando se aceleró el proceso de transformación y especialización de la isla en una economía de plantación esclavista, basada en el monocultivo del azúcar, que a partir de la década de 1840 llevará a la isla a convertirse en el primer exportador mundial del blanco producto. Es justo en estas décadas cuando se gesta la idea de la Cuba del azúcar, de los grandes ingenios azucareros, que dominará la imagen de la isla hasta prácticamente nuestros días. Sobre este tema, véase Moreno 2001; Fernández de Pinedo 2002; Santamaría y García Álvarez 2004.

${ }^{7}$ La idea de la existencia de comisarios principales y, por tanto, de una jerarquía de estos oficiales aparece expresamente en la propia documentación: el 10 de noviembre de 1811 el tribunal de Cartagena «circuló a las comisarías principales de Santa Fe, Caracas, Panamá, Habana, Cuba y Puerto Rico» un despacho informándoles de los acontecimientos que llevaban a la extinción y exilio del tribunal y exhortándoles a que continuasen en el ejercicio de sus funciones (Certificación de Fermín Paniza y Navarro, Inquisición de Cartagena de Indias, 20 de noviembre de 1811. En «Testimonio de la Inquisición de Cartagena de Indias que recoge la documentación de todo lo ocurrido desde que el 11 de noviembre de 1811 se declaró la independencia de la provincia de Cartagena y hasta el exilio del referido tribunal», AGI, Indiferente General, 3014B, 5r-v. (La cursiva es mía). 8 No obstante que desde 1522 el único obispado de la isla se instaló en Santiago de Cuba, prácticamente desde los primeros momentos de la llegada de los españoles, la capital política, económica e intelectual de la isla se ubicó en La Habana, como ya se ha explicado. Esta 
que de estas dos comisarías principales dependieron otros comisarios que se localizaron en importantes núcleos de la isla, como por ejemplo en la villa central de Puerto Príncipe (actualmente Camagüey) y en la de Guanabacoa. ${ }^{9}$ Puerto Príncipe fue una villa que estuvo bajo la jurisdicción de la diócesis de Santiago de Cuba. A comienzos del siglo XIX, fue la segunda ciudad en población del obispado y la tercera en importancia en el contexto insular (después de La Habana y Santiago de Cuba); fue además un centro cuya actividad económica se vinculó a la ganadería, donde desde 1800 se situó la Audiencia —el máximo tribunal de justicia de la isla - tras la independencia de Santo Domingo; y, finalmente, un núcleo cuya población ha sido tradicionalmente caracterizada por la historiografía como levantisca, violenta e inclinada al autogobierno. ${ }^{10}$ Por su parte, Guanabacoa estaba localizada al este de La Habana. Erigida como pueblo de indios en 1553 , en 1743 recibió el título de villa y fue entre los primeros núcleos en beneficiarse del proceso de expansión del azúcar que desde el hinterland habanero irradió hacia el este de la capital. ${ }^{11}$

La pérdida del archivo de la Inquisición de Cartagena durante el proceso de independencia del virreinato es uno de los mayores obstáculos que impiden conocer cuál fue la estructura de estas comisarías en la isla y

preeminencia se confirmó a partir de 1607 cuando la isla se dividió en dos gobernaciones y se concedió al gobernador de La Habana el título de capitán general de la isla, lo cual le convirtió además en la máxima autoridad militar. Esta evidente contradicción entre el hecho de que la capitalidad de la isla estuviese en la ciudad habanera y la sede eclesiástica en Santiago de Cuba, llevó a muchos obispos a fijar extraoficialmente su residencia en La Habana, mientras que el cabildo catedralicio permaneció en Santiago. Las solicitudes de traslado de la catedral o de una nueva división eclesiástica de la isla fueron una constante, pero no fueron escuchadas hasta 1789 en un contexto de acelerado desarrollo económico y demográfico de la parte occidental de la isla, debido al boom azucarero. En 1803, Santiago de Cuba fue elevada a arzobispado y se le asignaron las diócesis de La Habana y Puerto Rico como sufragáneas. Véase, Fernández Mellén 2014: 27-44; Torres-Cuevas y Leiva Lajara 2007: 92-95; Irisarri 2003: 94-95; Amores 2000: 488; Macías 1978.

9 Oficio de Juan Nepomuceno Arango al gobernador y capitán general de Cuba, Puerto Príncipe, 2 de septiembre de 1817, AGI, Ultramar, 86, 429r-434r; Esteban Manuel de Elosua y Abarrategui al Tribunal de Cartagena de Indias, La Habana, 30 de enero de 1784, Archivo Histórico Nacional [en adelante: AHN], Inquisición, 1605, exp. 3.

${ }^{10}$ Juárez 1929; Amores y Vázquez 2003: 63; Armas 1958.

${ }^{11}$ Hernández González 2000. 
su funcionamiento. ${ }^{12} \mathrm{~A}$ falta de estudios que aborden sistemáticamente y de forma integral el funcionamiento y la ramificación inquisitorial en la isla, parece que esta fue la estructura de base sobre la cual el Santo Oficio neogranadino se mantuvo en la isla desde 1610 hasta la declaración de independencia del territorio del virreinato en 1819.

A comienzos del siglo XIX, los comisarios principales de la isla fueron miembros de la curia diocesana y del alto clero, como el referido Esteban Manuel de Elosua, quien ejerció el comisariato de La Habana desde $1800 .{ }^{13}$ De Elosua fue anteriormente notario de esta comisaría y secretario del primer obispo de la diócesis de La Habana, Felipe José Trespalacios (1789-1799), durante la primera etapa de su episcopado. ${ }^{14}$ En 1795 una real orden mandó la separación de De Elosua de la secretaría

${ }^{12}$ Aquí nos queremos hacer eco de una realidad que Torres Puga ha tratado en trabajos recientes: cómo fue la desaparición de los archivos inquisitoriales durante las guerras de independencia americanas. Parece que algunos fueron quemados por las autoridades autónomas y en otras fueron los propios inquisidores y las consecuencias de los acontecimientos bélicos los que determinaron que esta documentación no haya llegado hasta nuestros días (Torres Puga 2017a: 45-62). En el caso de Cartagena de Indias, tras proclamarse la independencia de la provincia, el 11 de noviembre de 1811, el tribunal del Santo Oficio se exilió a Santa Marta llevando consigo su archivo, a excepción de los fondos referidos a esta diócesis que entregó a su obispo fray Custodio Díaz Merino, en quien delegó todas las facultades del tribunal y le transfirió «la jurisdicción apostólica, real y ordinaria» («Testimonio de la Inquisición de Cartagena de Indias que recoge la documentación de todo lo ocurrido desde que el 11 de noviembre de 1811 se declaró la independencia de la provincia de Cartagena y hasta el exilio del referido tribunal», AGI, Indiferente General, 3014B, ff. 9r-10r); Oficio de Juan José Oderiz y Prudencio de Castro y Sarralde, al presidente del Gobierno Supremo, Sala del decano de Cartagena, 11 de diciembre de 1811, ib.: ff. 13v-14r; Oficio del presidente del Gobierno Supremo, Ignacio Cavero, a José Oderiz y Prudencio de Castro, Cartagena, 11 de diciembre de 1811, Ib., ff. 20r-20v). Apenas un año después, el obispo siguió los pasos del Tribunal, emprendiendo a su vez un exilio que el 18 de febrero de 1813 le llevó a desembarcar en La Habana, donde falleció el 12 de enero de 1815 (Arrazola 1963: 4; Mesa 1911: 312). Sobre las tensas y difíciles relaciones de la Inquisición de Cartagena con las autoridades revolucionarias y el posterior exilio del tribunal, véase Torres Puga 2017b: 107-111.

${ }^{13}$ Esta realidad es confirmada para otros territorios americanos. Martínez Rosales señala que la mayoría de estos comisarios pertenecieron a familias respetables y que "predominaron, salvo excepciones, los eclesiásticos seculares» (1984: 418).

${ }^{14}$ Esteban Manuel de Elosua y Abarrategui al Tribunal de Cartagena de Indias, La Habana, 30 de enero de 1784, AHN, Inquisición, 1605, exp. 3. 
como consecuencia de una campaña que se emprendió en la Corte contra él y otros principales empleados de la curia diocesana, la cual buscó desacreditarlos bajo las acusaciones de manipular al obispo y de aprovecharse de su edad e invalidez a fin de gestionar los asuntos eclesiásticos en beneficio personal. A pesar de la gravedad de estas denuncias y la subsiguiente medida preventiva, en pocos años De Elosua consiguió rehabilitarse, de forma que durante el siguiente episcopado, el de Juan José Díaz de Espada y Landa (1802-1832), ejerció como promotor fiscal de la curia al mismo tiempo que la comisaría del Santo Oficio cartagenero, empleos al que se sumó el título honorífico de inquisidor apostólico que le concedió el Consejo de Regencia. ${ }^{15}$

Por su parte, el comisario de Santiago de Cuba, el licenciado Tomás del Monte y Mesa fue a su vez canónigo magistral y comisario subdelegado de Cruzada. ${ }^{16}$ Parece que la misma tendencia se dio entre los comisarios «delegados», quienes fueron elegidos entre el clero parroquial: en 1784 se proponía para la villa de Guanabacoa al presbítero y sacristán mayor de la parroquia de Asunción, José Antonio Rivero, quien fue a su vez familiar del obispo de Cuba, Santiago José Hechavarría y Elguezúa (17691788); mientras que en la segunda década del siglo XIX, el comisario de Puerto Príncipe era el cura de la parroquia mayor de Santa María Juan Nepomuceno Arango, quien en 1814 recibió además el título de consultor propietario del tribunal de Cartagena en premio a su celo "contra la herejía y la infidencia». ${ }^{17}$

El 11 de noviembre de 1811, la vida del Santo Oficio de Cartagena y su propia existencia se vio sacudida por primera vez como consecuencia

${ }^{15}$ Fernández 2014: 60 y 65-66; auto del obispo de La Habana, La Habana, 25 de mayo de 1813, AGI, Ultramar, 84.

${ }^{16}$ Juramento de los miembros de la comisaría de Santiago de Cuba, Santiago de Cuba, 20 de abril de 1811. En "Testimonio del expediente sobre juramento de las Cortes y Regencia hecho por el Santo Tribunal de Cartagena de Indias que manda hacerlo a las comisarías subalternas con las demás funciones religiosas que se previenen, consecuente con la real orden de veinte y nueve de septiembre del año pasado de mil ochocientos diez», AGI, Indiferente General, 3014 B, ff. 7v-10v.

${ }^{17}$ Oficio de Juan Nepomuceno Arango al gobernador y capitán general de Cuba, Puerto Príncipe, 2 de septiembre de 1817, AGI, Ultramar, 86, f. 431v. 
del decreto de la Junta Suprema de Cartagena de Indias, que ordenó la abolición y «extrañamiento» del tribunal neogranadino y concedió a sus miembros el plazo de 15 días para restituirse a España. ${ }^{18} \mathrm{La}$ institución inquisitorial era identificada como un instrumento más del dominio y de la represión colonial, y era vista como un oprobio para la religión, en cuyo nombre había cometido numerosas barbaridades. El decreto de abolición fue solo el punto de llegada de un largo enfrentamiento entre las autoridades de la junta cartagenera y el tribunal inquisitorial. A finales de diciembre de 1811, sus miembros partieron a un largo exilio, que les llevó primero a Santa Marta y después a Portobelo, de donde regresarían con el restablecimiento de la autoridad real por el capitán general Francisco Montalvo y Ambulodi. ${ }^{19}$ En este contexto, el normal y pleno ejercicio de la actividad de la Inquisición de Cartagena y la de sus territorios dependientes, como fue el caso de las comisarías de Cuba, se vieron dificultados.

En abril de 1811, la comisaría de Santiago de Cuba se había visto envuelta en un expediente con el gobernador interino de la ciudad, Pedro Celestino Duhart, como consecuencia del despacho del tribunal de Cartagena de 22 de enero que ordenó a las comisarías subalternas jurar la soberanía de las Cortes, obediencia al Consejo de Regencia y celebrar una misa de Te Deum seguida de tres días de rogativas públicas. El acto fue apelado ante la referida autoridad oriental por el presbítero José Antonio Suárez, a quien la misma comisaría seguía un proceso. Duhart ordenó la suspensión de los actos. Suárez acusaba a la comisaría de haber obedecido las órdenes de un tribunal que se hallaba en territorio revolucionario, con el que desde el 7 de noviembre de 1810 la capitanía

18 "Testimonio de la Inquisición de Cartagena de Indias que recoge la documentación», AGI, Indiferente General, 3014B, 3v-4v. Este decreto es citado también por Torres Puga 2017b: 108-109.

${ }^{19}$ Respecto a los inicios del proceso independentista en Nueva Granada, véase Torres Puga 2017b: 108; sobre el tribunal de Cartagena de Indias en el siglo XVIII, véase Molina 1984a: 1353-1367 y 1984b: 1411-1422. 
general había prohibido todas las comunicaciones. ${ }^{20}$ La orden decretada por Duhart, unida a la obediencia de los miembros de la comisaría, dio alientos a Suárez para continuar su causa contra la comisaría, porque, según escribía el propio comisario, el presbítero consideraba:

destruidos e inexistentes los tribunales del Santo Oficio para evadirse con su causa de la jurisdicción y conocimiento de este tribunal, exponiendo la citada providencia del veinte por único motivo de la suspensión decretada, el haber venido la disposición comunicada por Cartagena, cuya correspondencia (como prohibida por bando publicado en esta plaza, según se dice, de orden del capitán general de esta plaza), denunció el dicho eclesiástico, acusando de infractora a esta comisaría. ${ }^{21}$

La ruptura de comunicaciones entre el territorio del virreinato y La Habana buscaba impedir que las noticias de la revolución y de las ideas sobre las que se asentaba esta llegasen a contaminar la isla y provocasen la explosión de un movimiento emancipador similar al de los territorios continentales. El temor de las autoridades coloniales no era infundado en vista de los acontecimientos que se habían desarrollado en la isla desde que se tuvo conocimiento de los sucesos ocurridos en Espańa en 1808. ${ }^{22}$ De forma similar a lo que ocurrió en otros territorios de la América continental española, como consecuencia de la invasión de las tropas napoleónicas de la península Ibérica, de las abdicaciones de Carlos IV y Fernando VII en Bayona y la nómina de José Bonaparte como rey de España, también en Cuba los cabildos de las principales ciudades de la isla (La Habana, Santiago

20 «Testimonio del expediente sobre juramento de las Cortes y Regencia hecho por el Santo Tribunal de Cartagena de Indias que manda hacerlo a las comisarías subalternas con las demás funciones religiosas que se previenen, consecuente con la real orden de veinte y nueve de septiembre del año pasado de mil ochocientos diez», AGI, Indiferente General, 3014B.

21 Tomás José del Monte y Mesa al Consejo de Regencia, Santiago de Cuba, 14 de mayo de 1811, AGI, Indiferente General, 3014B. Finalmente, el Consejo de Regencia dictaminó que la comisaría continuase con su gobierno y que completase los actos que faltaban para el reconocimiento y juramento de las Cortes y del Consejo de Regencia, es decir, la misa de Te Deum y las rogativas públicas (Minuta del dictamen del Consejo de Regencia, 9 de noviembre de 1811, AGI, Indiferente General, 3014B).

${ }^{22}$ Vázquez Cienfuegos 2008. 
de Cuba y Puerto Príncipe) se apresuraron a presentar sus propuestas para crear juntas autónomas que buscaron asumir el gobierno en nombre del legítimo soberano Fernando VII frente al intruso Bonaparte. Estas juntas no llegaron a constituirse. ${ }^{23}$ Sin embargo, una ola de exaltación patriótica contra el enemigo francés sacudió toda la isla. En este contexto, en 1809 se decretó la expulsión y confiscación de los bienes de la población francesa, que fue acompañada de un movimiento tumultuario protagonizado por un grupo de jóvenes de color en La Habana y los campos aledaños, el cual fue sofocado por la autoridad civil en colaboración con la religiosa. ${ }^{24}$

A esta situación de inestabilidad política se sumaron las primeras conspiraciones contra el gobierno peninsular, como la que encabezaron Román de la Luz y Joaquín Infante en 1810, que buscó independizar la isla, y que puso en jaque nuevamente a las autoridades civiles y religiosas de la isla. ${ }^{25}$ En 1811 el presbítero cubano José Agustín Caballero presentó ante las cortes gaditanas su proyecto de reforma para el régimen administrativo de la isla. En medio de todo ello, la isla recibía masas de emigrantes que llegaron huyendo de los procesos revolucionarios del continente. ${ }^{26}$ En este contexto, tenso y conflictivo, un elemento más vino a desestabilizar la situación de la isla: el decreto de libertad de imprenta de 10 de noviembre de 1810 del Consejo de Regencia. La orden, si bien excluyó las publicaciones de temas religiosos, que quedaron sometidos a la revisión de una junta de censura, integrada por seglares y destacados miembros del clero de la diócesis de La Habana, favoreció la explosión de publicaciones periódicas de diverso signo, que denunciaron la corrupción

${ }^{23}$ Fernández Mellén 2007; Portuondo 2008; Vázquez Cienfuegos 2009d y 2013.

${ }^{24}$ Vázquez Cienfuegos 2009d. Entre 1790 y 1804, como consecuencia de la rebelión negra de Saint-Domingue, que culminó con la proclamación de la república de Haití de ese último ańo, numerosos refugiados franceses llegaron a Cuba, donde contribuyeron a la transformación de la economía insular con sus capitales y la introducción de nuevas técnicas. Su situación cambiaría a partir de los acontecimientos de la península, que los convirtió en miembros siempre susceptibles y sospechosos de colaborar con una nación enemiga (Vázquez Cienfuegos 2005 y 2009c).

${ }^{25}$ Morales Padrón 1972: 351-357; Franco 1977.

${ }^{26}$ Caballero 1999: 214-236. 
y abusos del sistema y que discutieron las reformas necesarias, sin que faltaran las críticas al clero. ${ }^{27} \mathrm{Al}$ respecto, Elosua escribió años después:

a pesar de semejante celo y de la vigilancia de los ministros reales de V. M. con motivo de la libertad pasada y de la extinción de los Tribunales de la Fe, que la siguió, se introdujeron obras de indicada clase y se imprimieron en esta ciudad con el objeto sin duda de atacar la sana moral, las costumbres y la subordinación de las legítimas potestades, multitud de discursos y papeles, entre ellos el Contrato Social de Rousseau, traducido del idioma francés al español para que de esta forma llegase a la mejor comprensión general y los innumerables ejemplares (de los que el exponente ha recogido muchos) tuviesen fácil expendio, como se logró, y juntamente la irreligión y la relajación de costumbres en esta populosa ciudad de un comercio vastísimo hasta con extranjeros de diversas sectas, de suerte que apareció el desorden y la confusión, confusión del uso de aquellas obras e impresos y de la decantada libertad. ${ }^{28}$

La libertad de imprenta se sumaba al problema de la circulación de libros, que durante el siglo XVIII se había visto favorecida por los conflictos bélicos que asolaron el Caribe. Estos multiplicaron el tránsito y contacto de personas, ideas, libros y panfletos, como ocurrió, por ejemplo, durante la ocupación británica de La Habana en 1762, con la emigración francesa que tuvo lugar tras la revolución haitiana entre 1791 y 1804 o como consecuencia del comercio de neutrales, que prácticamente de forma ininterrumpida rompió el monopolio comercial español entre 1791 y 1814 y que permitió el intercambio con naciones extranjeras, fundamentalmente con los Estados Unidos. ${ }^{29}$ La coyuntura política y económica internacional favoreció y multiplicó la penetración en Cuba de las ideas ilustradas, de los autores franceses y protestantes, de las nuevas ciencias y técnicas, que encontraron un ambiente receptivo entre la población de la isla y, fundamentalmente, entre la elite habanera, que en toda esta literatura halló una respuesta al orden y la flexibilidad

27 Sánchez Baena 2009: 98 y 101-111. Sobre la libertad de imprenta, véase también Russel-Jensen 1998 y Medina 1964.

${ }^{28}$ Representación de Esteban Manuel Elosua al rey, La Habana, 29 de abril de 1816, AGI, Indiferente General, 3014B, (La cursiva es mía).

${ }^{29}$ González-Ripoll Navarro 2000: 334; Vázquez Cienfuegos 2009a y 2009d. 
que la nueva realidad económica y social de la isla demandaba. ${ }^{30}$ Es ilustrativo de esta realidad el hecho de que hubo padres que enviaron a sus hijos a estudiar a los Estados Unidos, una república federal con un sistema parlamentario representativo y de población mayoritariamente de confesión protestante; un país que fue visto con recelo por la monarquía, porque vio con temor la posibilidad de que a través de él se produjera un contagio de ideas que cuestionaran el dominio colonial. ${ }^{31}$

En este contexto, en 1811 el comisario de la Inquisición en La Habana consultó a qué tribunal debía enviar los expedientes para su resolución. ${ }^{32}$ Como comisario, sus funciones se limitaban a recoger las denuncias, realizar la instrucción del proceso y enviar el expediente al tribunal de la ciudad neogranadina para su resolución; ${ }^{33}$ sin embargo, las comunicaciones con el viejo virreinato estaban cortadas. En España, el Consejo de la Suprema se había disuel to por la imposibilidad de sus miembros de mantenerse y solo funcionaban algunos tribunales de distrito «con escasos recursos pecuniarios y con menos personal que antes de la guerra»; ${ }^{34}$ mientras que en América continuaba su actividad el tribunal de México y parece que a duras penas el de Lima. ${ }^{35}$ En medio de esta precaria situación, donde los tribunales inquisitoriales americanos luchaban por sobrevivir, sus miembros vieron abrirse un nuevo frente de batalla a partir de 1813 en los debates de las cortes constitucionales de Cádiz y en la feroz crítica de la opinión pública a ambos lados del Atlántico, amparada en la mencionada libertad de imprenta. ${ }^{36}$ En España, los debates de las

${ }^{30}$ González-Ripoll Navarro 2000: 336.

${ }^{31}$ El capitán general el marqués de Someruelos al ministro de Gracia y Justicia, la Habana, 13 de julio de 1799, AGI, Cuba, 1752.

32 AGI, Ultramar, 152, no 64.

${ }^{33}$ Sobre las funciones de los comisarios y el prestigio que el empleo confirió a sus miembros, véanse Guerrero Galván 2010; López Vela 2010: 354-355; Miranda Ojeda 2007: 163-190.

${ }^{34}$ La Parra y Casado 2013: 88.

35 Torres Puga 2017b; Vassallo 2017. Para una visión general de la Inquisición en España y Portugal y sus territorios coloniales en su último periodo, véase La Parra y Casado 2013; Cicerchia 2017; Marcocci y Paiva 2013: 331-448.

36 Peña Rambla 2016: 73-233; La Parra y Casado 2013: 99-126; Torres Puga 2004: 97-101. 
cortes gaditanas culminaron con el decreto de abolición del tribunal de 22 de febrero de ese año. Por primera vez, los miembros de la Inquisición quedaron despojados de sus funciones y solo conservaron sus sueldos a la espera de que se les diese un nuevo destino. ${ }^{37}$

En la diócesis de La Habana, su obispo recibió el decreto de abolición por despachos de 23 de febrero y de 6 de marzo de la secretaría de Gracia y Justicia y de la Gobernación de Ultramar respectivamente. Incluso antes de que la capitanía general de la isla, al frente de la cual se hallaba Juan Ruíz de Apodaca, tuviese conocimiento del mismo, ${ }^{38}$ el obispo Díaz de Espada se apresuró a su ejecución:

Estando abolidos por la Nación en los decretos de las Cortes de 22 de febrero último los tribunales llamados de Inquisición por motivos tan justos como dignos para que se borren de la memoria, si es posible, unos tribunales odiosos y de oprobio a una Nación como la Espańola, acreedora a mejores felicidades por sus leyes, administración de justicia y por la legítima autoridad que la ejercen, en cuyo conocimiento se han detestado dichos tribunales y la usurpación hecha a los obispos de su debido conocimiento en los asuntos en que aquellos entendían y se han mandado quitar y destruir todos los cuadros, inscripciones y pinturas en que estén consignados los castigos y penas que imponían. ${ }^{39}$

El decreto fue publicado inter missarum solemnia en todas las iglesias de la diócesis en los tres domingos siguientes a su recepción. Como consecuencia del mismo, el comisario de La Habana cesó en sus funciones. El propio obispo describe cómo se desarrolló este episodio:

de movimiento propio el presbítero D. D. Esteban Manuel de Elosua, comisario en propiedad de la Inquisición de esta ciudad ha muchos años y promotor fiscal de la curia eclesiástica, quien por sus servicios en aquel ramo había igualmente obtenido los honores de tal Inquisidor, y aún él mismo hizo quitar de la puerta de su casa las insignias inquisitoriales desde el momento en que se publicó dicha abolición, pues que desde entonces no hay honores para sus ministros, antes por el contrario es un deshonor cualquier señal afectada de haberlos tenido, como detestados por la nación. ${ }^{40}$

${ }^{37}$ Real decreto de 22 de febrero de 1813, AGI, Ultramar, 84.

38 Juan Ruíz Apodaca a José de Limonta, La Habana, 8 de julio de 1813, AGI, Ultramar, 84.

39 Auto de Díaz de Espańa, La Habana, 25 de mayo de 1813, AGI, Ultramar, 84.

${ }^{40} \mathrm{Ib}$. 
El decreto de supresión tuvo una vigencia de pocos meses. Su ejecución se hizo "sin contradicción, ni rumor alguno, sino con la obediencia y docilidad que era de esperar de tan justa disposición», ${ }^{41}$ a excepción del expediente que ocasionó la negativa del presbítero Mariano de Arango, quien desde 1810 disfrutaba del título de Inquisidor honorario que le fue concedido por la Regencia — al igual que lo había obtenido el comisario Elosua-, a dejar de usar los manguillos azules que el obispo identificaba como una insignia del abolido tribunal. ${ }^{42}$ En 1814, la vuelta al trono español de Fernando VII supuso el restablecimiento del absolutismo y la supresión de toda la obra constitucional de las cortes gaditanas. El decreto de 21 de julio abrió las puertas al restablecimiento en su anterior planta de la Inquisición y restituyó el prestigio que habían gozado sus miembros; mientras que el de 31 de julio restauró los tres tribunales americanos. ${ }^{43}$ Fue en este contexto que, en 1816, el comisario de La Habana presentó su propuesta de establecer un tribunal de la Inquisición en La Habana, la cual suponía una reorganización de los distritos territoriales del tribunal en América.

\section{UN PROYECTO DE INQUISICIÓN PARA LA HABANA}

Los proyectos de creación de nuevos distritos inquisitoriales en América fueron una constante desde el establecimiento de los primeros tribunales, los de México y Lima, entre 1570 y 1571. A estos dos tribunales se sumó la actividad del de Cartagena de Indias en $1610 .{ }^{44}$ Desde este momento y hasta el decreto de las Cortes de Cádiz de 1813, la división inquisitorial americana establecida por la monarquía española permaneció inalterable, incluso cuando sufrió las convulsiones del proceso

${ }^{41}$ Juan José Díaz de Espada al Consejo de Regencia, La Habana, 30 de junio de 1813, AGI, Ultramar. 84.

42 Todo el expediente sobre el presbítero Mariano Arango en AGI, Ultramar, 84. Desde una perspectiva comparada, véase, por ejemplo, lo ocurrido en el caso del virreinato de La Plata, donde, al igual que en Cuba, solo existieron comisarías (Vasallo 2017).

${ }^{43}$ La Parra y Casado 2013: 135.

${ }^{44}$ Para una historia general de la Inquisición, véase Pérez Villanueva y Escandell Bonet 1984. 
emancipador americano. A lo largo de los casi dos siglos que median entre esas dos fechas, la gran extensión de los distritos inquisitoriales dificultó que sus ministros ejercieran una jurisdicción efectiva, lo cual fue la razón de que aparecieran propuestas para la creación de nuevos tribunales. La problemática que enfrentó la jurisdicción inquisitorial fue común a toda la división político-administrativa y eclesiástica de América durante la etapa colonial. Las dimensiones del territorio, la dispersión de la población, unida a la incapacidad de esta estructura de adaptarse a ambas realidades, impidieron que la corona ejerciera un control total y efectivo sobre el territorio americano.

A partir del siglo XVIII, cuando el expansionismo de las potencias europeas amenazó la soberanía española sobre los territorios americanos, la Corona comenzó a concienciarse de la necesidad de emprender un conjunto de reformas que permitiesen reforzar el control y proporcionaran un mejor conocimiento del territorio. Ese impulso reformista se dio fundamentalmente a partir del reinado de Carlos III (1759-1788) y fue continuado por su hijo Carlos IV (1788-1808). La nueva política borbónica respecto a los territorios americanos se dirigió a subsanar esas deficiencias con la restructuración de las entidades político-administrativas y judiciales, a un mayor control fiscal con la implantación del régimen de intendencias o a facilitar la labor eclesiástica de unos obispos a partir de la fundación de nuevos obispados.

El proyecto de reforma eclesiástica de la monarquía borbónica tuvo como consecuencia el reforzamiento de la autoridad de unos obispos, que, formados en los presupuestos del regalismo borbónico, fueron auténticos funcionarios reales y ejercieron su jurisdicción de forma autoritaria y absoluta, al punto que entraron en fuerte conflicto con otras jurisdicciones eclesiásticas exentas de su autoridad, como, por ejemplo, la de los regulares, incluso la de la misma Inquisición. ${ }^{45}$ Este es el tipo de obispo que nos encontramos al frente de las dos diócesis en que estaba dividida la isla de Cuba a principios de siglo XIX. ${ }^{46}$ Conocer este rol

\footnotetext{
45 Artola Renedo 2013; Rodríguez López Brea 1999: 355-371.

${ }^{46}$ Fernández Mellén 2014; Irisarri Aguirre 2003.
} 
que el reformismo borbónico asignó a los prelados permite ver cómo el proceso de transferencia de la jurisdicción inquisitorial a los obispos, del que hablan diferentes autores, ${ }^{47}$ no es sino una evolución lógica de un proceso que se había iniciado ya desde mediados del siglo XVIII, y que a partir de la década de 1810 se vio favorecido por la política eclesiástica de las cortes liberales y por el proceso emancipador americano. Este, en el caso del virreinato de Nueva Granada, llevó — como se ha visto- al exilio de los miembros del tribunal de Cartagena y a obstaculizar el desarrollo de su actividad hasta que en 1813 la Regencia decretó la extinción del tribunal, cuya aplicación en La Habana fue aplaudida por su obispo. En una carta de este prelado al Consejo de Regencia, llegó a dar gracias a Dios por su destrucción. ${ }^{48}$

Si nos ceñimos al testimonio que el comisario De Elosua da como balance de su actividad inquisitorial, parece que hacia 1816 esta se había dirigido casi exclusivamente al control de ideas, de la lectura y difusión de los libros:

Es indubitable que la lectura de libros prohibidos ha ocasionado en todos tiempos la corrupción de costumbres y traído incalculables perjuicios a la santa religión católica y a la soberanía. Bajo tal concepto el exponente, ejercitado en el cumplimiento de su sagrado ministerio y comisión, ha vigilado infatigablemente para impedir el uso pernicioso de aquellos. Y así es que recogió innumerables. En comprobación de esta verdad y de su celo redujo a cenizas públicamente en solo una vez tres mil setecientos volúmenes, fuera de otras de cuya operación elevó cuenta a la Superioridad del distrito con el expediente instruido que formó al intento. ${ }^{49}$

${ }^{47}$ Torres Puga 2017b: 100-101; Quezada Lara 2016; La Parra y Casado 2013.

${ }^{48}$ Juan José Díaz de Espada al Consejo de Regencia, La Habana, 30 de junio de 1813, AGI, Ultramar, 84.

${ }^{49}$ Representación de Esteban Manuel de Elosua al rey, La Habana, 29 de abril de 1816, AGI, Indiferente General, 3014B. Este dato de la purga de libros ha sido ya referido por algunos autores como reflejo de la actividad inquisitorial en la isla. Entre otros, véase García Pons 1951: 238. 
Desconocemos a qué expediente se refería exactamente en su representación De Elosua y si este tuvo respuesta del tribunal cartagenero. ${ }^{50}$ El comisario completaba su informe-propuesta con la denuncia de otros males que invadían la sociedad y los peligros que la acechaban: entre los primeros, la impiedad y la irreligión; entre los segundos, el protestantismo y la masonería. ${ }^{51}$ Por lo que se refiere a aquellos, escribía:

La impiedad y la irreligiosidad harto comunes han estrechado al R. Obispo Diocesano [Juan J. Díaz de Espada] a prohibir los rosarios que por las calles se cantaban todas las noches del año y salían de varios templos y el vía crucis en las de los viernes de las Cuaresmas, a causa de los repetidos insultos e irreverencias que se cometían, experimentándose en alguno de aquellos una lluvia de pedradas con el objeto de robar las alhajas a la santísima imagen de Nuestra Señora del Rosario [...]. Igual prohibición habrá tal vez de decretar el enunciado R. Obispo con respecto a la procesión del Santo Entierro de Cristo Señor Nuestro por el desorden repetido muchas veces la tarde del Viernes Santo último y en la del año pasado de 1814, en las que personas atrevidas hicieron diferentes robos en dichas procesiones, valiéndose en el acto de ejecutarlos de armas cortas, de manera que la confusión y el atropellamiento de los concurrentes fue grande y escandalosísimo, habiendo sucedido el propio atentado dentro de la iglesia del convento de San Juan de Dios, de la que sale la antedicha procesión, a tiempo que se representaba el descenso del cuerpo del Redentor de la Cruz. ${ }^{52}$

La preservación y vigilancia de la religión y de sus prácticas eran ya unas esferas de competencia exclusiva de la jurisdicción diocesana y de la autoridad civil. Sin embargo, todavía estaba reservada a los comisarios de la Inquisición el control de aquellas proposiciones consideradas heréticas y que atentaban contra la religión y el dogma. ${ }^{53} \mathrm{~A}$ ojos del comisario de

${ }^{50}$ Sobre el archivo de la Inquisición de Cartagena de Indias, ver nota 12.

${ }^{51}$ Hernández González 2012; Martínez Fernández 2001: 9-71; Soucy 2006: 35-67.

52 Representación de Esteban Manuel de Elosua, La Habana, 29 de abril de 1816, AGI, Indiferente General, 3014B.

53 Justo por esos años, el comisario de Puerto Príncipe, Juan Nepomuceno Arango, se hizo eco de que había recibido una denuncia "[de] que se estaba profanando el templo, faltándose al culto de la Majestad por dos eclesiásticos que escandalizaban en la conferencia moral, defendiendo el uno una opinión errónea y perniciosa y ambos en altercación de gritos, injuriándose con dicterios heréticos, de que resultaba el dejar morir 
La Habana, la actuación conjunta del capitán general y la del obispo era insuficiente para poner fin a la «impiedad» $\mathrm{y}$ «libertinaje» que dominaba la sociedad; no obstante, él mismo era consciente que sus limitadas competencias como comisario le impedían actuar en consecuencia, como ya había podido comprobar unos años antes. ${ }^{54}$ En diciembre de 1809 con motivo de haberse introducido en el puerto

varios géneros extranjeros destinados a vestidos de señoras y a otros usos domésticos, $[\ldots]$ en que aparecen estampadas diferentes imágenes religiosas y otras pinturas de objetos muy dignos de veneración, como son la santa cruz, en que fuimos redimidos, y la insignia consagrada al sumo sacerdocio, que es la mitra episcopal, y por esto, que no es de ninguna manera tolerable una profanación tan sacrílega y tan opuesta al respeto que exige todo lo que tiene relación íntima con aquellos objetos. ${ }^{55}$

El obispo de La Habana mandó que en el plazo de tres días todas las telas fueran recogidas y llevadas a la comisaría del Santo Oficio para que se cortase y quemase "cuanto pueda escandalizar a las almas piadosas", bajo la pena de excomunión mayor a todo el que desobedeciese. ${ }^{56} \mathrm{~A}$ principios de enero de 1810, miles de telas ardieron durante tres días en el patio del convento de San Agustín. ${ }^{57}$ Casi dos meses después, en la comisaría de La Habana, se presentaba el maestro sastre Isidro

negros bozales sin el bautismo ni aún sub conditione [...] me propuse sin estrépito de proceso concurrir al acto de aquella conferencia y por medio de una prudente y sabia amonestación precaver no solamente el error, sino también mandar cesasen los dicterios hereticales, a cuyo fin les leí el canon quinto décimo del Concilio Arausicano en el cap. primero y el edicto general de la Suprema Inquisición, relativo al asunto" (Oficio de Juan Nepomuceno Arango al gobernador y capitán general de Cuba, Puerto Príncipe, 2 de septiembre de 1817, AGI, Ultramar, 86, ff. 431v-432r).

${ }^{54}$ Representación de Estaban Manuel de Elosua, La Habana, 29 de abril de 1816, AGI, Indiferente General, 3014B.

${ }^{55}$ Edicto de Juan José Díaz de Espada, partido de El Cerro, 6 de diciembre de 1809. En «Expediente que Esteban Manuel de Elosua envía al Consejo de Regencia junto a la representación de 2 de agosto de 1811», AGI, Indiferente General, 3014B, ff. 25v-26r. ${ }^{56} \mathrm{Ib}$.

${ }^{57}$ Certificación del bachiller José María Mateos, presbítero domiciliario del obispado de La Habana y notario del Santo Oficio, La Habana, 12 de enero de 1810, AGI, Indiferente General, 84, ff. 26r-27r. 
Moreno denunciando que se le habían llevado unas cintas donde aparecía una cruz para coserlas en las libreas de los cocheros y lacayos, y en las mantas de la caballería del carruaje de Julia Parreño, viuda del regidor alférez mayor del cabildo Miguel Ciriaco Arango, miembros ambos de una de las principales familias de la élite habanera y padres del conocido abogado Francisco Arango y Parreño y del ya mencionado presbítero Mariano Arango. ${ }^{58}$ Haciendo extensivo el contenido del edicto diocesano de diciembre anterior, De Elosua mandó a la familia Arango retirar estas insignias por profanarse en ella la cruz al vestirlas unos esclavos que se dedicaban «a los usos más bajos y humillantes de la sociedad». ${ }^{59} \mathrm{La}$ actuación del comisario fue denunciada ante el Santo Oficio de Cartagena, que, a pesar de que dio la razón al comisario en las argumentaciones que habían impulsado su actuación, al mismo tiempo le conminó a sujetarse

a la Cartilla, promoviendo cualquier acto o suceso instructivamente sin pasar a oficiar, ni a practicar diligencias que le están absolutamente impedidas sin expreso mandamiento del tribunal, que no se entrometa en casos que provoquen estrépito judicial u oficial, sin expresa orden nuestra; que en nada innove acerca de la librea del citado Arango, ni de cualquiera otro individuo de su distrito; sobreseyendo en todo este procedimiento que nos ha causado particular desagrado y respecto que el tribunal no puede disimular de que sus comisarios cometan el menor abuso, singularmente con personas de alto carácter y distinguidas magistraturas, y que nuestro comisario se ha excedido con la responsabilidad y riesgo que a su tiempo podrá reclamarse. ${ }^{60}$

Ante llamadas de atención como esta por parte del tribunal de Cartagena, no es de extrańar que en 1816 De Elosua escribiese:

${ }^{58}$ Denuncia de Isidro Moreno, La Habana, 21 de febrero de 1810, AGI, Indiferente General, 84, ff. 1r-2r.

59 «¿Y cuándo más hollada la cruz, que puesta para adornar una bestia o como insignia o divisa de un esclavo destinado a los usos más bajos y humillantes de la sociedad?» (Oficio de De Elosua a Francisco Arango, La Habana, 4 de abril de 1810, Indiferente Genreal, 84, ff. 9v-13r.).

${ }^{60}$ Despacho del tribunal de Cartagena de Indias al comisario de La Habana, Tribunal de Cartagena de Indias, 20 de junio de 1810, Indiferente General, 84, ff. 33v-34v. (La cursiva es mía). 
no le queda arbitrio para valerse de ejecutivos procedimientos que atajen y sofoquen la corrupción y el libertinaje, que en La Habana han llegado al más alto grado. Canciones y palabras las más obscenas son las que se oyen por sus calles, proferidas tan sin reparo por personas de todas condiciones grandes, pequeñas y hasta por los niños guiados del mal ejemplo, que no las contiene ni el respeto que debe causarles la presencia de los sacerdotes y personas condecoradas por sus empleos, ni la inmediación a los templos, que a la sazón que en ellos se están celebrando los Divinos Misterios se producen en alta voz las propias obscenidades con notable escándalo de los piadosos y timoratos fieles, que asisten a dichos misterios y ofensa de los castos oídos de las vírgenes consagradas a Jesucristo. ${ }^{61}$

El informe del comisario describe una situación alarmante con el claro fin de hacer más evidentes la necesidad y los beneficios de establecer un tribunal de la Inquisición en La Habana, que englobase los obispados de Puerto Rico, Santo Domingo (dependientes del de Cartagena), además de la provincia y obispado de Mérida de Yucatán (dependiente de la de México). El Comisario — que aspiraba a ser nombrado primer inquisidor por los servicios que había prestado al Santo Oficio durante más de 36 años- explicaba que:

La erección de un Tribunal del Santo Oficio es no sólo el más oportuno, eficaz y conveniente [remedio], sino de necesidad absoluta, que independiente del de Cartagena de Indias dicte prontas y activas providencias, capaces a extinguir de una vez semejantes amenazas. Lo exige esta extensísima y numerosa capital, que por sus ricas y ventajosas producciones tiene vastísimas relaciones de comercio con nuestra nación y las extranjeras y lo exigen también las muchas y grandes poblaciones que comprende esta isla de Cuba. ${ }^{62}$

El nuevo tribunal de la fe estaría integrado por dos inquisidores, quienes ejercerían su actividad auxiliados de un cuerpo de "ministros subalternos» que, sin embargo, el comisario no se detiene en identificar. ${ }^{63}$ De Elosua valoraba que dos eran los inconvenientes que en la península se podrían

${ }^{61}$ Representación de Esteban Manuel de Elosua, La Habana, 29 de abril de 1816, AGI, Indiferente General, 3014B.

${ }^{62} \mathrm{Ib}$.

${ }^{63} \mathrm{Ib}$. 
oponer a su proyecto y, en consecuencia, anticipaba las soluciones que se les podría dar: el primero de ellos y el principal, el de la falta de recursos (un problema que debían enfrentar también los tribunales en la península) y, en segundo lugar, el de la inexistencia de un edificio dónde establecer las oficinas. Este último problema se presentaba como el de más fácil solución: De Elosua proponía instalarlo en el oratorio de San Felipe Neri, que se hallaba en el centro de la ciudad:

enclaustrado con repartimientos altos y bajos bastante capaces para formar de ellos todas las oficinas que sean precisas. Su extensión ofrece además alojamiento cómodo a los inquisidores, y aún podrá construirse cárcel para los reos. Su iglesia servirá de capilla al Tribunal, sin perjuicio de que el administrador de las rentas de dicho oratorio llene en aquella las cargas a que es obligado, como lo ha practicado hasta ahora. Y que los cuatro capuchinos sacerdotes con los dos legos y cuatro donados, que lo ocupan en calidad de colegio de misión, se trasladen al hospicio de San Isidro, así como los seis regulares de la menor observancia que en este residen, al gran convento de su instituto que tienen en esta propia ciudad. ${ }^{64}$

Respecto al primero de los problemas, el comisario de La Habana proponía que los dos inquisidores fuesen dotados con los fondos de la conocida como canonjía extinta de la Inquisición de cada una de las dos catedrales de la isla, además de las tres de las catedrales de los tres obispados que preveía que pasaran a integrar el nuevo distrito inquisitorial. ${ }^{65}$ De Elosua calculaba que el sueldo de cada uno de los dos inquisidores debería ser de 4.000 pesos anuales: ${ }^{66}$

\footnotetext{
${ }^{64} \mathrm{Ib}$.

${ }^{65}$ En 1627, una bula de Urbano VIII del 10 de marzo había mandado que en todas las catedrales de América se suprimiese una de las canonjías con el objeto de destinar su dotación a los ministros de Inquisición (Real cédula de 30 de septiembre de 1852, Archivio Segreto Vaticano [en adelante ASV], Archivio della Nunziatura di Madrid, 341).

${ }^{66}$ En 1815, De Elosua solicitó al rey que se le aumentase su sueldo en 2.000 pesos «para recompensar su trabajo, mantener la decencia de su empleo y proveer a los enunciados gastos». El comisario de La Habana se refería especialmente al dinero que invertía anualmente en la celebración de la fiesta de San Pedro Mártir de Verona, cuando en la víspera y en el día exponía en su casa el «estandarte de la fe con el decoro correspondiente»
} 
con consideración al crecido costo que en La Habana tienen los géneros necesarios a la subsistencia y vestuario y a que con dicha cuota podrán presentarse con el decoro que requiere su distinguido empleo y carácter, dejándose a la prudencia de los propios inquisidores el seńalamiento de los salarios a los subalternos. ${ }^{67}$

El comisario contemplaba incluso la posibilidad de que las cantidades de la mencionada canonjía no fuesen suficientes y, en ese contexto, proponía que al mantenimiento de los inquisidores del Tribunal se destinase el conocido como «sobrante de la cuarta capitular» del cabildo catedralicio de La Habana. ${ }^{68}$ Los fondos para adaptar el oratorio a sus nuevas funciones saldrían de la "pensión compensatoria", que desde el momento de la erección de la diócesis de La Habana, esta debía pagar a Santiago de Cuba. ${ }^{69}$

(Esteban Manuel de Elosua a Fernando VII, La Habana, 18 de noviembre de 1815, AGI, Indiferente General, 3014B).

${ }^{67}$ Representación de Esteban Manuel de Elosua, La Habana, 29 de abril de 1816, AGI, Indiferente General, 3014B.

${ }^{68} \mathrm{Ib}$. En 1799, la Corona congeló la cuarta capitular, es decir, los salarios de los miembros del cabildo catedralicio de La Habana en base a lo que estas dignidades y prebendas habían percibido en el cuatrienio que finalizó en 1796. A partir de esa fecha, el conocido como «sobrante de esa cuarta capitular» fue ingresado en las arcas reales (véase Fernández Mellén 2014: 83).

${ }^{69}$ Tras la división de la isla en dos diócesis, las dos terceras partes del territorio quedaron bajo la jurisdicción del obispado de La Habana. Aquí se concentró el cultivo del azúcar, producto sobre el que - como ya se ha escrito- se fundamentó el proceso de crecimiento económico de la isla desde 1790. Desde el punto de vista de la recaudación decimal, esto supuso que la mayor parte de la renta decimal quedase adscrita a la nueva diócesis, en detrimento del obispado de Santiago de Cuba, cuyos ingresos se vieron sensiblemente reducidos con el reparto. El oriente era un territorio pobre, cuyos cultivos - fundamentalmente el café y el tabaco, unido al cultivo de otros productos considerados menoresestuvieron lejos de rendir las cantidades que se recaudaron con el azúcar. En este contexto, para compensar las diferencias de recaudación, se promulgó la real cédula de 1793 que estableció la demarcación de la diócesis y la distribución decimal de la isla. Por esta cédula, la diócesis de La Habana se vio obligada a pagar de la masa de sus diezmos y de los excusados 65.000 pesos anuales — conocidos como "pensión compensatoria»- al obispado de Santiago de Cuba (Fernández Mellén 2014: 116-125). El comisario Elosua proponía que, además del sobrante de la cuarta capitular, se destinasen 60.000 pesos de la pensión compensatoria a financiar la adaptación material del edificio destinado al 


\section{A LA ESPERA DE TIEMPOS MÁS FELICES}

El 14 de junio de 1816, el capitán general Juan Ruíz de Apodaca envió a Madrid el proyecto de De Elosua junto con un oficio donde apoyaba la propuesta y la pretensión del comisario de ser nombrado primer inquisidor. ${ }^{70}$ Pasado todo al Consejo de Indias, el 20 de enero de 1817, este, además de manifestar su extrañeza por el hecho de que el plan no hubiera sido presentado por vía del Tribunal de Cartagena y sin el conocimiento del obispo de La Habana y el arzobispo de Santiago de Cuba, dictaminó pasarlo al Consejo de la Inquisición. ${ }^{71}$ La Suprema confirió al arcediano electo de la catedral de La Habana, Manuel Sobral y Bárcena, la comisión de realizar un plan sobre la propuesta de crear un Tribunal de la Inquisición en La Habana, cuyas conclusiones fueron recogidas en un informe que en agosto de ese mismo año fue enviado al inquisidor general, Francisco Javier Mier y Campillo. ${ }^{72}$

Manuel Sobral se hallaba en la capital del reino tras prorrogar su embarque a Cuba bajo el pretexto de asuntos de familia, de la realización de las pruebas de limpieza de sangre para la orden de Carlos III y para recibir los honores de inquisidor del Tribunal de Cartagena. El comisionado había jugado un relevante papel durante el periodo de las Cortes de Cádiz, cuando realizó diversos servicios a favor de la causa realista, informando desde Francia sobre los pasos de la potencia enemiga durante el sitio de Cádiz o encargado por la Regencia de negociar en el país galo la liberación de Fernando VII. ${ }^{73}$ A la fecha en que la Suprema le concedió la referida comisión, no tenemos constancia que Sobral hubiera estado en Cuba, pero sí de que estuvo informado de todo lo que en ella ocurría. Pensamos que en este conocimiento de la realidad insular se encuentra la explicación más plausible a la afirmación de Figueroa y Miranda que

tribunal de la Inquisición (Representación de Esteban Manuel de Elosua, La Habana, 29 de abril de 1816, AGI, Indiferente General, 3014B).

${ }^{70}$ Oficio no 32 de Juan Ruíz Apodaca a Pedro Cevallos, La Habana, 14 de junio de 1816, AGI, Ultramar, 391.

${ }^{71}$ Informe del Consejo de Indias en sala 1a, 20 de enero de 1817, AGI, Ultramar, 391.

72 Oficio del Inquisidor General, Madrid, 26 de noviembre de 1817, AGI, Ultramar, 392.

73 Todo el expediente en AHN, Estado, 3566, exp. 48. 
hace al arcediano electo uno de los «enemigos acérrimos» del obispo Díaz de Espada. ${ }^{74}$ Sobral conocía la gestión del prelado de La Habana y nos consta que no aprobó la decisión con que ejecutó el decreto de abolición de la Inquisición, ni sus opiniones contrarias al Tribunal y métodos:

El obispo de Cartagena [fray Custodio Díaz Merino] había visto con horror el decreto mandado por las Cortes sobre la extinción del Tribunal de la Inquisición y desaprobaba cuanta innovación se pretendían hacer en la Iglesia de Espańa por los nuevos reformadores. Y aquel de La Habana [el obispo Díaz de Espada] fue el primero de América que se apresuró a felicitarla y que empleó todo esfuerzo para manifestar con sus obras aquella especie de independencia de la Corte romana tanto conforme a las ideas de aquellos que en Pistoya la quisieron sostener. ${ }^{75}$

Desde 1815, en el Tribunal de Inquisición de Corte se seguía un proceso contra el obispo de La Habana por la acusación de masón. En nuestras investigaciones pudimos concluir que las acusaciones fueron promovidas por los familiares del mismo obispo exiliado de Cartagena de Indias — del que se hace eco la carta de Sobral—, quienes se sintieron ofendidos por la actitud del obispo de La Habana, que se negó a sostener con las rentas de la mitra al de Cartagena durante su exilio en la isla entre 1813 y 1815 , fecha esta última de su muerte. ${ }^{76}$ Las declaraciones de los testigos del expediente contra Díaz de Espada — quienes en mayor o menor medida habían tenido algún enfrentamiento con él— delatan claramente un ejercicio episcopalista de su autoridad por parte de este diocesano, el cual se concretó en medidas como la secularización y dispensa de votos que había concedido a religiosos durante el periodo

\footnotetext{
${ }^{74}$ Figueroa y Miranda 1975: 15.

${ }^{75}$ Informe reservado de Manuel Sobral y Bárcena a Pietro Gravina, Madrid, 1816, ASV, Segretaria di Stato Esteri, busta 592, fasc. 5, 18v-19r. (La traducción es mía). Para una breve información de la actuación del obispo de Cartagena, véase la nota 12, y sobre su posicionamiento: representación de fray Custodio Merino al presidente del gobierno Supremo, Cartagena, 2 de diciembre de 1811. En «Testimonio de la Inquisición de Cartagena de Indias que recoge la documentación de todo lo ocurrido desde que el 11 de noviembre de 1811 se declaró la independencia de la provincia de Cartagena y hasta el exilio del referido tribunal», AGI, Indiferente General, 3014B, 10v-12v.

${ }^{76}$ Fernández Mellén 2014: 288.
} 
liberal, su regalismo y su antirromanismo, delatado por afirmaciones como "aquí no hay papa, más que yo» ${ }^{77}$. Parece evidente que entre los familiares del obispo de Cartagena y el propio Sobral (no es de extrañar que las dos partes se conocieran a juzgar por las noticias que este da al nuncio) existió una posición común contra el obispo que hunde sus raíces en diferentes orígenes: la de los familiares del obispo Merino ya ha sido brevemente explicada, mientras que las de Sobral quedan al descubierto en la declaración que recoge el referido expediente. Tras su elección como arcediano, se informó de cuál era el estado de la diócesis:

Las noticias que deseaba saber era muy fácil adquirir por los muchos individuos de aquella ciudad que están en esta corte, unos destinados en ella por el gobierno y otros en solicitud de acomodo para aquella isla. Las que unánimemente me dieron todos del R. Obispo, confieso a V.S., que al paso que trastornaron mi ánimo, haciéndome vacilar si admitiría o no mi destino, fueron de tal consideración y tamaño que las creí exageradas y casi imposibles que pudieran verificarse en aquel pastor. En esta duda hubiera permanecido a no haberme convencido de su certeza, con bastante sentimiento de mi corazón, una porción de expedientes que en esta misma época se están mirando en el Supremo Consejo de Indias concernientes a dicho prelado. ${ }^{78}$

Por tanto, el reformismo, el constitucionalismo y las acusaciones por masonería son razones suficientes que explican la oposición que pudiera sentir el arcediano electo contra su futuro obispo. El informe de Sobral sobre la necesidad de establecer el tribunal en Cuba recoge y desarrolla los principales argumentos del comisario de La Habana, y constituye un manifiesto apologético sobre los tribunales de la Fe, su trabajo y la necesidad de los mismos, que - a su juicio — había quedado particularmente demostrada durante las Cortes de Cádiz y con los episodios que tuvieron lugar después de la publicación del decreto de abolición del Tribunal. Sobral presentaba la larga lista de razones que, a su juicio, justificaban la necesidad de establecer el Tribunal de la Inquisición. Después de referirse

77 Fernández Mellén 2014: 287-292. Los detalles del proceso fueron publicados por Martínez Millán 1993: 47-55.

${ }^{78}$ Informe de Sobral que se une a los antecedentes del expediente por orden del Tribunal, Inquisición de Corte, 25 de agosto de 1816, AHN, Inquisición, leg. 2194², no 2. 
a las particularidades geográficas de la isla, el teólogo se refiere a sus singulares características económicas y poblacionales, que ya habían sido subrayadas por el comisario como peligros que amenazaban la religión y la soberanía española:

Las costumbres de aquel país en lo general son sencillas y muy semejantes a las que tienen las provincias internas en el reino de la Nueva España; pero no deja de notarse alguna diferencia considerable en estas, cuando se observan las que tienen los pueblos inmediatos a sus puertos, principalmente en el de La Habana, donde nada se ignora de todo aquello que hoy día se llama Ilustración, ya por el continuado roce y comercio que tienen con los Estados Unidos, que es donde tiene su trono la impiedad y de donde salen, como de su origen, todas las ideas de independencia; $y$ ya porque las demás naciones europeas, que profesan diferentes creencias y concurren a sus puertos, dan a entender con las costumbres, que se les advierte, con las doctrinas de los libros que introducen y con las palabras que derraman, que no es solo la sed del oro la que los conduce a aquellas riberas, sino también el deseo de ilustrar a su modo, propagando las máximas anti-religiosas con que han trastornado la Europa, bajo las esperanzas halagüeńas de libertad e independencia, que aquellos mismos no han conocido. ${ }^{79}$

\section{Y continuaba explicando:}

Allí, donde la población interior, en la mayor parte, son unos negros bozales, poco o nada instruidos en la religión, los mismos naturales del país sin las ideas sólidas del cristianismo, habitando pueblos sumamente distantes unos de otros, y por lo mismo difíciles de instruir; que al primer golpe de vista casi tocan con las manos una isla sublevada por los negros de Santo Domingo; que a poco andar tropiezan con la Jamaica, con la Trinidad y con otra inmensidad de ellas, habitadas de piratas y de hombres inmorales en sumo grado; que a sus puertos forzosamente deben abordar todos los buques procedentes de la Costa Firme y Veracruz, en los que no es nada difícil, ni de extrañar, se comuniquen noticias que puedan influir contra la tranquilidad pública y a favor de las ideas de independencia; que en toda la grande extensión, que contiene aquella isla, no se cuenta un tribunal del

${ }^{79}$ Copia de la exposición presentada al Exmo. e Yllmo. Sor. Obispo Inquisidor General sobre la necesidad de establecer un tribunal del Santo Oficio en la Isla de Cuba, por D. Manuel del Sobra y Bárcena, teólogo, consultor y examinador sinodal del arzobispado de Toledo y de Segovia, y arcediano de la catedral de La Habana, Madrid, 1817, AGI, Ultramar, 392. 
Santo Oficio, sino una que otra comisaría, cuyas facultades son limitadas al tribunal principal, que reside en Cartagena de Indias. ${ }^{80}$

Significativamente, tras la enumeración de la larga lista de peligros que atentaban contra la religión y el estado, Sobral se preguntaba:

¿Quién será capaz de sujetar los primeros pasos que quiera dar la corrupción de costumbres para entronizarse en el interior de la isla después de haber corrompido la capital? ¿Será por ventura la religión y sus ministros? ¡Oh!, ¡Qué desgracia...! V. Exa. sabe, o tiene ideas, del pastor [el obispo de La Habana] que gobierna aquel rebaño, y esto basta para que yo me afirme más y más en la opinión de que en la ciudad de La Habana [...] es de absoluta necesidad el establecimiento de un Tribunal del Santo Oficio. ${ }^{81}$

Por tanto, el tribunal se presentaba como un eficaz remedio para contener los males de la isla y por extensión contener la autoridad de un obispo cuyo reformismo y episcopalismo quedaban probados con sus medidas de gobierno. ${ }^{82} \mathrm{El}$ informe de Sobral concluía detallando los medios económicos disponibles para ejecutarlo y solo difería del comisario de La Habana en el lugar donde podría establecerse, ya que propone que sea el convento de los betlemitas. ${ }^{83} \mathrm{~A}$ comienzos de 1819, en La Habana aún no se había tenido noticia del dictamen del inquisidor general Mier y Campillo, quien había concluido que no había fondos para la ejecución del proyecto y que era preciso esperar «tiempos felices» $\mathrm{y}$ "que no era negocio urgente». ${ }^{84}$ Ante el silencio de Madrid, en marzo de ese año, De Elosua volvió a insistir en su propuesta, esta vez de la mano del nuevo capitán general José Cienfuegos, quien —como había hecho

${ }^{80}$ Ib. La cursiva es mía.

${ }^{81}$ Ib. La cursiva es mía.

${ }^{82}$ Fernández Mellén 2014.

${ }^{83}$ Copia de la exposición presentada al Exmo. e Yllmo. Sor. Obispo Inquisidor General sobre la necesidad de establecer un tribunal del Santo Oficio en la Isla de Cuba [...], Madrid, 1817, AGI, Ultramar, 392.

${ }^{84}$ Oficio del Inquisidor General, Madrid, 26 de noviembre de 1817, AGI, Ult, 392. De hecho, la falta de recursos de la Inquisición fue uno de los grandes problemas que tuvo que enfrentar desde su restablecimiento hasta la nueva supresión del Tribunal. Sobre este particular, véase La Parra y Casado 2013: 140-141. 
su predecesor - secundó la propuesta del comisario. ${ }^{85}$ Finalmente, el 18 de junio el inquisidor general, Jerónimo Castillón y Salas, sentenciaba la imposibilidad de llevar a cabo el proyecto y desmontaba los argumentos del comisario:

los fundamentos en que apoya el citado Elosua la propuesta de que se establezca en La Habana un tribunal de Inquisición, independiente de el de Cartagena de Indias son tan verdaderos, obvios y generales que según su espíritu deberían establecerse en todos los puntos y ciudades principales de América; que con los tres que se hallan establecidos se han mantenido aquellos dominios hasta la insurrección en el debido orden y tranquilidad, se ha respetado la religión católica y venerados sus ministros y prelados. ${ }^{86}$

Castillón y Salas concluía que el establecimiento de un tribunal demandaba «tiempos tranquilos, serenidad y unidad de ideas rectas y sanas» y apuntaba la falta de fondos, como una de las razones que impedía ejecutarlo. ${ }^{87}$ Por tanto, oposición y falta de fondos eran las razones que desaconsejaban la realización del proyecto. El 23 de junio de 1819, el Consejo de la Suprema ratificó el dictamen del inquisidor general en una sentencia que fue comunicada al presidente del Consejo de Indias y al capitán general de la isla. ${ }^{88}$ Las palabras del inquisidor general son un ejemplo de los cambiantes tiempos que le había tocado vivir desde el restablecimiento del tribunal en 1814. En este sentido, Emilio La Parra y María Ángeles Casado señalan que durante el sexenio absolutista el relevo del prestigio y la actividad del Tribunal en la persecución de la heterodoxia religiosa, a la que se sumó la de los delitos políticos, fueron tomados por los obispos y las autoridades civiles correspondientes. ${ }^{89}$ Precisamente, el rechazo a la propuesta coincidió con la resolución del

${ }^{85}$ Esteban Manuel de Elosua a José Cienfuegos, La Habana, 28 de marzo de 1819; y Oficio no 125 de José Cienfuegos a Juan Esteban Lozano de Torres, La Habana, 30 de marzo de 1819, AGI, Indiferente General, 3014B.

${ }^{86}$ Dictamen del Inquisidor General y el Consejo de la Suprema, 18 de junio de 1819 , AGI, Indiferente General, 3014B.

${ }^{87} \mathrm{Ib}$.

${ }^{88} \mathrm{Ib}$.

${ }^{89}$ La Parra y Casado 2013: 148. 
expediente contra el obispo. A finales de 1819, se sobreseyó temporalmente la causa contra él por falta de pruebas. ${ }^{90}$

\section{CONCLUSIÓN}

Una vez más — como muchas otras reformas—, la lógica de la política y de los intereses de Estado quedó supeditada al estado financiero de una Corona, que sufrió un déficit permanente y que centró sus esfuerzos en buscar nuevas fuentes de recursos. La propuesta de establecer un tribunal en La Habana fue el último intento de aquellos que aún veían en el viejo instrumento y en el temor que su nombre despertaba dentro de la sociedad de instaurar un arma para luchar contra nuevos enemigos: masonería y constitucionalismo. Sin embargo, la situación de la institución avocaba al naufragio cualquier intento de reforma y voces, como la del gobernador eclesiástico de la diócesis de Puerto Rico en sede vacante, Nicolás Andrade, que en noviembre de 1824 clamaba por el restablecimiento de la Santa Inquisición como un antídoto para la contención a los «libertinos y exaltados», como el «eficaz arbitrio que ha cortados los progresos a la impiedad", fueron rémoras de tiempos pasados que estaban lejos de responder a la realidad de un Tribunal que todavía hubo de vivir una segunda abolición y restablecimiento antes de su definitiva desaparición en $1834 .{ }^{91}$

\section{BIBLIOGRAFÍA}

Álvarez Alonso, Fermina. 1999. La Inquisición en Cartagena de Indias durante el siglo XVII. Madrid: Fundación Universitaria Española.

Amores, Juan Bosco. 2000. Cuba en la época de Ezpeleta (1785-1790). Pamplona: Eunsa.

Amores, Juan Bosco y Sigfrido Vázquez Cienfuegos. 2003. «Violencia y conflictividad social: una aproximación al estudio de la violencia en la Cuba colonial (1785-1810)». En Opartný, Josef (ed.). Cambios y revoluciones en el Caribe hispano de los siglos XIX y XX. Praga: Universidad Carolina, 45-64.

${ }^{90}$ Fernández Mellén 2014: 292.

${ }^{91}$ Nicolás Alonso Andrade y San Juan al rey, Puerto Rico, 30 de noviembre de 1824, AHN, Ultramar, 2004, exp. 8, $\mathrm{N}^{\circ} 17,1 \mathrm{r}-5 \mathrm{r}$. 
Armas Medina, Fernando de. 1958. «La Audiencia de Puerto Príncipe (1775-1853)». Anuario de Estudios Americanos. Número XV, 273-370.

Arrazola, Roberto. 1963. Documentos para la historia de Cartagena. Cartagena: Edición Oficial.

Artola Renedo, Andoni. 2013. De Madrid a Roma. La fidelidad del episcopado en España (1760-1833). Gijón: Trea.

Brambilla, Elena. 2006. La giustizia intolleranti: Inquisizioni e tribunal confessionali in Europa (secoli IV-XVIII). Roma: Carocci.

Caballero, José Agustín. 1999. Obras. La Habana: Imagen Contemporánea.

Cicerchia, Andrea. 2017. "Las últimas Inquisiciones entre Europa y América: un recorrido histórico y una reflexión comparativa». En Vasallo, Jacqueline, Rodriguez Lourenço, Miguel y Susana Bastos Mateus (coords.). Inquisiciones. Dimensiones comparadas (siglos XVI-XIX). Argentina: Brujas, 21-43.

Crespo Vargas, Pablo L. 2018. La Inquisición española y las supersticiones en el Caribe hispano, 1610-1632. Puerto Rico: Centro de Estudios e Investigaciones del Sur Oeste de Puerto Rico.

Fernández de Pinedo, Nadia. 2002. Comercio exteriory fiscalidad: Cuba (1794-1860). Leioa: Universidad del País Vasco.

Fernández Mellén, Consolación. 2007. «A la zaga de La Habana: el intento autonomista de Puerto Príncipe de 1809». Ibero-Americana Pragensia Suplementum. Número 19, 145-156.

Fernández Mellén, Consolación. 2014. Iglesia y poder en La Habana: Juan José Díaz de Espada, un obispo ilustrado (1800-1832). Bilbao: Universidad del País Vasco.

Figueroa y Miranda, Miguel. 1975. Religión y politica en la Cuba del siglo XIX. El Obispo Espada visto a la luz de los Archivos romanos, 1802-1832. Miami: Ediciones Universal.

Franco, José Luciano, 1977. Las conspiraciones de 1810 y 1812. La Habana: Ciencias Sociales.

García Pons, César. 1951. El obispo Espada y su influencia en la cultura cubana. La Habana: Ministerio de Educación.

González-Ripoll Navarro, María Dolores. 2000. «Ocio, lecturas y escritura en la Ilustración cubana». Revista de Indias. Número 219, volumen LX, 331-343.

Greenleaf, Richard E. 1981. La Inquisición en Nueva España: siglo XVI. México: Fondo de Cultura Económica.

Greenleaf, Richard E. 1988. Zumárraga y la Inquisición mexicana, 1536-1543. México: Fondo de Cultura Económica.

Guerrero Galván, Luis René. 2010. De acciones y transgresiones. Los comisarios del Santo Oficio y la aplicación de la justicia inquisitorial en Zacatecas, siglo XVIII. México: Universidad Autónoma de Zacatecas.

Hampe Martínez, Teodoro. 1998. Santo Oficio e historia colonial: aproximaciones al Tribunal de la Inquisición de Lima (1570-1820). Lima: ediciones del Congreso de Perú. 
Hernández González, Manuel. 2000. «La pugna por la jurisdicción de Guanabacoa entre su cabildo y el de La Habana en el siglo XVIII». Tiempos de América. Número 7, 3-9.

Hernández González, Manuel. 2012. Liberalismo, Masonería y Cuestión Nacional en Cuba, 1808-1823. Santa Cruz de Tenerife: Idea.

Irisarri Aguirre, Ana. 2003. El Oriente cubano durante el gobierno del obispo Joaquin de Osés y Alzúa (1790-1823). Pamplona: Universidad de Navarra.

Juárez Cano, Jorge. 1929. Apuntes de Camagüey. Camagüey: Imprenta el Popular.

La Parra, Emilio y María Ángeles Casado. 2013. La Inquisición en España: agonía y abolición. Madrid: Catarata.

Le Riverent Brusone, Julio. 2005. "Arrate, la mirada inteligente al pasado». En Arrate, José María (ed.). Primeros historiadores, siglo XVIII. La Habana: Imagen Contemporánea, V-XIV.

López Vela, Roberto. 2010. «Commissario del Sant'Uffizio, Spagna». En Prósperi, Adriano (coord.). Dizionario Storico dell Inquisizione. Pisa: Scuola Normale, volumen I, 354-355.

Macías, Isabelo. 1978. Cuba en la primera mitad del siglo XVII. Sevilla: Escuela de Estudios Hispanoamericanos.

Maqueda Abreu, Consuelo. 2000. Estado, Iglesia e Inquisición en Indias. Un permanente conflicto. Madrid: Centro de Estudios Políticos y Constitucionales.

Marcocci, Giuseppe y José Pedro Paiva. 2013. História da Inquisição portuguesa, 1536-1821. Lisboa: A Esfera dos Livros.

Marrero, Leví. 1976. Cuba: economía y sociedad. Madrid: Playor, volumen 5.

Martínez Fernández, Luis. 2001. Protestatism and Political conflict in nineteenthCentury Hispanic Caribbean. New Jersey: Rutgers University Press.

Martínez Garnica, Armando. 2008. «La eclosión juntera en el Nuevo Reino de Granada». Secuencia. Revista de historia y ciencias sociales. Número 72, 123-143.

Martínez Millán, José. 1993. "Juan José Díaz de Espada, obispo de La Habana, ¿un prelado masón?». En Ferrer Benimelli, José Antonio (coord.). Masonería española y América. Zaragoza: Centro de Estudios Históricos de la Masonería Española. Volumen 1, 47-55.

Martínez Rosales, Alfonso. 1984. «Los comisarios de la Inquisición en la ciudad de San Luis Potosí, 1621-1820». En Soberanes Fernández José Luis (coord.). Memoria del III Congreso de historia del derecho mexicano. México: Universidad Nacional Autónoma de México, 409-429.

Medina, José Toribio. 1899. Historia del Santo Oficio de la Inquisición en Cartagena de Indias. Santiago de Chile.

Medina, José Toribio. 1964. La imprenta en La Habana (1707-1810). Ámsterdam: Israel.

Mesa, Carlos Eduardo. 1977. "Primeras diócesis neogranadinas y sus prelados». Missionalia Hispánica. Números 100-102, 305-332. 
Miranda Ojeda, Pedro. 2007. «Las comisarías del Santo Oficio: funciones y funcionarios en la estructura inquisitorial de Yucatán, 1571-1820». Descatos. Número 25, 163-190.

Molina Moreno, José Luis. 1984a. "Tribunal de Cartagena de Indias». En Pérez Villanueva, Joaquín y Bartolomé Escandell Bonet, Historia de la Inquisición en España y América. Madrid: Biblioteca de Autores Cristianos /Centro de Estudios Inquisitoriales, I, 1353-1367.

Molina Moreno, José Luis. 1984b. «Cartagena de Indias». En Pérez Villanueva, Joaquín y Bartolomé Escandell Bonet. Historia de la Inquisición en España y América. Madrid: Biblioteca de Autores Cristianos /Centro de Estudios Inquisitoriales, I, 1411-1422.

Morales Padrón, Francisco. 1972. "Conspiraciones y masonería en Cuba (18101826)». Anuario de Estudios americanos. Volumen XXIX, 343-377.

Moreno Fraginals, Manuel. 2001. El ingenio. Barcelona: Crítica.

Peña Rambla, Fernando. 2016. La Inquisición en las Cortes de Cádiz. Un debate para la historia. Castelló de la Plana y Cádiz: Universitat Jaume I y Universidad de Cádiz. https://doi.org/10.6035/Humanitats.2016.49

Pérez Villanueva, Joaquín y Bartolomé Escandell Bonet. 1984. Historia de la Inquisición en España y América. Madrid: Biblioteca de Autores Cristianos y Centro de Estudios Inquisitoriales, 2 volúmenes.

Portuondo, Olga. 2008. Cuba: constitución y liberalismo (1808-1841). Santiago de Cuba: Oriente.

Quezada Lara, José Luis. 2016. ¿¿Una inquisición constitucional? El tribunal protector de la Fe del arzobispo de México, 1813-1814. Michoacán: Colegio de Michoacán.

Rodríguez López Brea, Carlos María. 1999. «Secularización, regalismo y reforma eclesiástica en la España de Carlos III: un estado de la cuestión». Espacio, Tiempo y Forma. Número 12, 355-371. https://doi.org/10.5944/etfiv.12.1999.3387

Russel Jensen, Larry. 1998. Children of colonial despotism: press, politics and culture in Cuba, 1790-1840. Tampa: University of South Florida Press.

Sánchez Baena, Juan José. 2008. «Sobre libros en «Indias»: de su existencia y comercio en Cuba entre los siglos XVI y XVI». En Cervera Salinas, Vicente y Adsuar Fernández, María Dolores (coords.). Alma América: in honorem Victorino Polo. Murcia: Universidad de Murcia. Volumen 2, 340-362.

Sánchez Baena, Juan José. 2009. El terror de los tiranos. La imprenta en la centuria que cambió Cuba (1763-1868). Castelló de la Plana: Universitat Jaume I.

Santamaría García, Antonio y Alejandro García Álvarez. 2004. Economía y colonia. La economía cubana y la relación con España (1765-1902). Madrid: Consejo Superior de Investigaciones Científicas e Instituto de Historia.

Soucy, Dominique. 2006. Masonería y nación. Redes masónicas y políticas en la construcción identitaria cubana (1811-1902). Las Palmas de Gran Canaria: Idea. 
Splendiani, Anna María. 1997. Cincuenta años de Inquisición en el Tribunal de Cartagena de Indias, 1610-1660. Santa Fe de Bogotá: Pontificia Universidad Javeriana. Torres-Cuevas, Eduardo y Edelberto Leiva Lajara. 2007. Historia de la Iglesia Católica en Cuba. La Iglesia en las patrias de criollos (1516-1789). La Habana: Boloña.

Torres Puga, Gabriel. 2004. Los últimos años de la Inquisición en la Nueva España. México: Consejo Nacional para la Cultura y las Artes e Instituto Nacional de Antropología e Historia.

Torres Puga, Gabriel. 2017a. «Conservación y pérdida de los archivos de la Inquisición en la América española: México, Cartagena y Lima». En Vasallo Jacqueline, Rodríguez Lourenço, Miguel y Susana Bastos Mateus (coords.). Inquisiciones. Dimensiones comparadas (siglos XVI-XIX). Argentina: Brujas, 45-62.

Torres Puga, Gabriel. 2017b. «Crisis, resistencia y supresión de los tribunales inquisitoriales en España y América (1808-1813)». Ayer. Número 108, 99-123.

Vassallo, Jacqueline. 2017. «El fin de la Inquisición en el Río de La Plata en tiempos de revolución y guerras de la independencia». Ayer. Número 108, 79-97.

Vázquez Cienfuegos, Sigfrido. 2005. «La élite habanera y los refugiados franceses de Saint Domingue». En Navarro García, Luis (coord.). Élites urbanas en Hispanoamérica. Sevilla: Universidad de Sevilla, 213-228.

Vázquez Cienfuegos, Sigfrido. 2008. Tan difíciles tiempos para Cuba. El gobierno del marqués de Someruelos (1799-1812). Sevilla: Universidad de Sevilla.

Vázquez Cienfuegos, Sigfrido. 2009a. «Enemigos de La Habana entre los patriotas gaditanos». En Cuenca Toribio, José Manuel (coord.). Andalucía en la Guerra de Independencia (1808-1814). Córdoba: Universidad de Córdoba, 205-215.

Vázquez Cienfuegos, Sigfrido. 2009b. «Reacción de la población de color en La Habana ante los sucesos de 1808». En García Bernal, María Cristiana y Sandra Olivero Guidobono (coords.). El municipio indiano: relaciones interétnicas, económicas y sociales. Sevilla: Universidad de Sevilla, 351-368.

Vázquez Cienfuegos, Sigfrido. 2009c. «Santiago de Cuba durante la crisis de 1808». Iacobus. Números 25-26, 383-412.

Vázquez Cienfuegos, Sigfrido. 2009d. «Víboras en nuestro seno: franceses y afrancesados en Cuba durante la Guerra de Independencia». En García, Diego de Emilio y José Luis Martínez Sanz (coords.). El comienzo de la Guerra de Independencia. Madrid: Editorial Actas.

Vázquez Cienfuegos, Sigfrido. 2013. La Junta de La Habana: adaptación del Pacto colonial en Cuba en visperas de las independencias hispanoamericanas (18081810). Sevilla: Consejo Superior de Investigaciones Científicas y Diputación Provincial de Sevilla.

Fecha de recepción: 31/III/2020

Fecha de aceptación: 24/VI/2020 